\title{
Tetraether membrane lipid distributions in water-column particulate matter and sediments: a study of 47 European lakes along a north-south transect
}

\author{
Cornelia Iulia Blaga • Gert-Jan Reichart • \\ Oliver Heiri · Jaap S. Sinninghe Damsté
}

Received: 18 December 2007 / Accepted: 22 July 2008/Published online: 3 September 2008

(C) The Author(s) 2008. This article is published with open access at Springerlink.com

\begin{abstract}
We studied the distribution of glycerol dialkyl glycerol tetraethers (GDGTs) in water-column particulate matter and the top $5 \mathrm{~cm}$ of sediment from 47 lakes along a transect from southern Italy to the northern part of Scandinavia. Our objective was to investigate the biological sources and potential palaeoenvironmental applications of GDGTs in lacustrine sediments. Both archaea-derived isoprenoid and bacteria-derived branched GDGTs, produced by yet unknown soil bacteria, were identified in all lake sediments. GDGT distributions varied substantially. Crenarchaeotal GDGTs, including the characteristic GDGT crenarchaeol, were found in varying relative concentrations, and were more dominant in lakes from the Alps and some of the lakes from the more southern part of the latitudinal transect. In some lakes, we observed high amounts of the GDGT with no cyclopentane moieties relative to crenarchaeol. As
\end{abstract}

C. I. Blaga ( $\bigotimes)$ · G.-J. Reichart · J. S. Sinninghe Damsté Faculty of Geosciences, Organic Geochemistry, Utrecht University, Budapestlaan 4, 3584 CD Utrecht, The

Netherlands

e-mail: blaga@geo.uu.nl

O. Heiri

Institute of Environmental Biology, Section

Palaeoecology, Utrecht University, Budapestlaan 4,

3584 CD Utrecht, The Netherlands

J. S. Sinninghe Damsté

Royal Netherlands Institute for Sea Research (NIOZ),

P.O. Box 59, 1790 AB Den Burg, The Netherlands methanogenic Euryarchaeota are known to biosynthesise this GDGT predominantly, these Archaea, rather than Crenarchaeota, may be its dominant biological source. In most of the lakes, high amounts of soil-bacteria-derived, branched GDGTs ( $>40 \%$ of total GDGTs) indicated a substantial contribution from soil erosion. Branched GDGTs dominated, especially in the northern lakes, possibly related to high soil-erosion rates. In many of the lakes, soil input affects the distribution of isoprenoidal GDGTs and prevents the reliable application of the $\mathrm{TEX}_{86}$ temperature proxy for lake water temperature, which is based on in situ crenarchaeotal GDGTs production. In 9 out of the 47 lakes studied, the $\mathrm{TEX}_{86}$ temperature proxy could be used reliably. When we compared the TEX $_{86}$ correlation with annual and winter lake-surface temperature, respectively, the relationship between $\mathrm{TEX}_{86}$ and winter temperature was slightly stronger. This may indicate the season in which these GDGTproducing organisms have their peak production.

Keywords Organic geochemistry ·

Palaeoenvironmental reconstructions .

Archaea $\cdot$ Lake water temperatures

\section{Introduction}

Our knowledge of how climate varied in the past is based mostly on proxy indicators in environmental archives, such as the fossil remains found in marine and 
lacustrine sediments. Lake sediments are potentially detailed, accurate, and high-resolution recorders of continental climate, in part due to their rapid accumulation rates. Because of high biological productivity in inland water bodies and good preservation conditions, lake sediments typically contain more organic matter than marine sediments. The complex mixture of lipids, carbohydrates, proteins and other organic components (Meyers 2003; Rullkötter 2000) derived from organisms that lived in and near the lake holds information for reconstructing changes in both local and regional environments. However, to date, most organic geochemical methods used for environmental reconstruction were developed almost exclusively for the marine environment. In most cases, climate proxies established in the marine environment cannot be applied in lacustrine settings. For example, in contrast to marine sediments (Brassell et al. 1987; Schouten et al. 2003), organic geochemical proxies for reconstructing lakewater temperature were, until recently, scarce (Liu et al. 2006; Hou et al. 2007). Recent investigations indicate that membrane lipids of Crenarchaeota, a subgroup of the Archaea, also hold promise as recorders of past lake-surface temperature (Powers et al. 2004).

Archaea, one of the three domains of life, comprises three phyla: Crenarchaeota, Euryarchaeota and Korarchaeota. The first two occur ubiquitously in the environment. One characteristic by which Archaea can be distinguish from Bacteria and Eucarya is their core membrane lipid composition. This manifests predominantly in the isoprenoidal versus n-alkyl chain architecture, the $s n-2,3$ versus $s n-1,2$ stereochemistry of the glycerol moieties, and to a lesser degree, in the presence of ether instead of ester linkages (Koga et al. 1998a, b). In mesophilic environments such as marine and lacustrine water and sediments, an important group of Archaea that produce glycerol dialkyl glycerol tetraethers (GDGTs) are the non-thermophilic, pelagic Crenarchaeota, an abundant group of the marine and lacustrine picoplankton (Karner et al. 2001; Keough et al. 2003). The core membrane lipids, known to occur in the mesophilic Crenarchaeota, consist of GDGTs, which contain two glycerol head groups linked by two biphytanyl moieties with 0 to 3 cyclopentane moieties. The number of cyclopentane moieties in the GDGT structure is considered to be a key factor in the adaptation to temperature change. Crenarchaeol, the tetraether membrane lipid with one cyclohexane moiety and four cyclopentane moieties
(Sinninghe Damsté et al. 2002) and its regio-isomer form, together with GDGT-0, are characteristic mesophilic crenarchaeal GDGTs. Crenarchaeol is considered to be a specific marker for "cold" Crenarchaeota because it has been found primarily in the membrane composition of non-thermophilic Crenarchaeota from aquatic environments (Schouten et al. 2008a, b) although it has also been reported recently in a thermophilic nitrifier (de la Torre et al. 2008). Crenarchaeol was also found in terrestrial environments in relatively small amounts (Weijers et al. 2006a). GDGTs with 0-3 cyclopentane moieties have been shown to derive also from mesophilic Euryarchaeota capable of anaerobic oxidation of methane (Pancost et al. 2001; Aloisi et al. 2002).

The membrane lipid composition of marine Crenarchaeota is strongly correlated with sea-surface temperature (Schouten et al. 2002; Kim et al. 2008). The strong control of sea-surface temperature on crenarchaeotal lipid composition probably reflects a biological adaptation to the environment in which the microorganisms thrive. Based on this compositional difference related to temperature, the $\mathrm{TEX}_{86}$ (TetraEther indeX of tetraethers consisting of 86 carbon atoms) temperature proxy was developed and has been used to reconstruct seawater temperatures from different settings and time periods (e.g. Schouten et al. 2003; Sluijs et al. 2006; Huguet et al. 2006). The linear relationship between SST and $\mathrm{TEX}_{86}$ values in marine sediments is expressed by:

$$
\mathrm{TEX}_{86}=0.015 * \mathrm{SST}+0.28 \quad\left(\mathrm{r}^{2}=0.92, \mathrm{n}=41\right) .
$$

Powers et al. (2004) studied four large lakes from different climatic and geographic settings to test the applicability of the $\mathrm{TEX}_{86}$ proxy in freshwater environments and suggested that the $\mathrm{TEX}_{86}$ palaeothermometer can be used in lakes as well. In a follow-up study, this observation was extended to encompass 10 lakes (Powers 2005); the linear relationship between the mean annual lake surface temperature (LST) and the $\mathrm{TEX}_{86}$ values was almost identical to the one from the marine environments:

$\mathrm{TEX}_{86}=0.015 * \operatorname{LST}+0.29 \quad\left(\mathrm{r}^{2}=0.92, \mathrm{n}=10\right)$.

The $\mathrm{TEX}_{86}$-surface temperature relationship in marine and freshwater systems is in good agreement 
with mesocosm studies by Wuchter et al. (2004), who noted that salinity had no significant effect on $\mathrm{TEX}_{86}$. In the study by Powers (2005), the $\mathrm{TEX}_{86}$ palaeotemperature proxy was tested for 48 globallydistributed lakes and it was noted that $\mathrm{TEX}_{86}$ can be applied successfully only in large lake systems, while in small-sized lakes its applicability is limited by several factors that affect the GDGT distribution. First, in aquatic systems, other Archaea, not necessarily limited to the water column (e.g. nonextremophilic Euryarchaeota like methanogens), can thrive and biosynthesize some GDGTs that are identical to the ones produced by the aquatic Crenarchaeota. This may affect the distribution of sedimentary GDGTs and thus potentially bias $\mathrm{TEX}_{86}$ values and the reconstructed temperatures (cf. Weijers et al. 2006b). Second, allochthonous input of archaeal membrane lipids may influence the GDGT distribution in lake sediments. To estimate the input of allochtonous terrestrial isoprenoid GDGTs, Weijers et al. (2006b) suggested using the Branched and Isoprenoid Tetraether index (BIT; Hopmans et al. 2004) before calculating temperatures by means of $\mathrm{TEX}_{86}$ analysis. This index is based on the relative abundance of crenarchaeol and the three main, branched GDGTs produced by anaerobic soil bacteria. Values of this index range from 0 , implying no input of soil organic matter, to 1, indicating a dominant soil organic-matter input. Although the branched GDGTs by themselves do not pose a problem for calculating $\mathrm{TEX}_{86}$ values, high concentrations of these components indicate a high likelihood that crenarchaeol and other isoprenoidal GDGTs are partly soil derived (Weijers et al. 2006b).

For a broader application of the $\mathrm{TEX}_{86}$ temperature proxy to lake sediments, greater insight is needed into the overall distribution of crenarchaeotal lipids and possible confounding of $\mathrm{TEX}_{86}$ values, and thus temperature reconstructions. The aim of the present study is to: (i) investigate whether GDGTs in general are present along a north-south transect in European lakes, (ii) establish the relative distribution of the GDGTs in relation to ambient temperatures, and (iii) test for the different relative contribution of GDGTs produced by non-thermophilic Crenarchaeota, other archaea and anaerobic soil bacteria.

\section{Methods}

Study sites

Two field campaigns were carried out in January and July 2006, sampling 31 lakes along a south-north transect from Italy (Lago Grande di Monticchio $40^{\circ} 55^{\prime} \mathrm{N}, 15^{\circ} 36^{\prime} \mathrm{E}$ ) to the northern part of Scandinavia (Torneträsk $68^{\circ} 21^{\prime} \mathrm{N}, 18^{\circ} 48^{\prime} \mathrm{E}$ ) (Fig. 1). Water samples were taken from near the lake surface (ca. $1 \mathrm{~m}$ ), at mid depth in the water column (which varied depending on the maximum depth of the lake), and at the lake bottom (to a maximum depth of $110 \mathrm{~m}$ ). One to five litres of water were filtered through $0.7-\mu \mathrm{m}$ glass fibre filters until the capacity of the filter was reached. Lake sediments were collected using a gravity corer. In addition to this sample set, 16

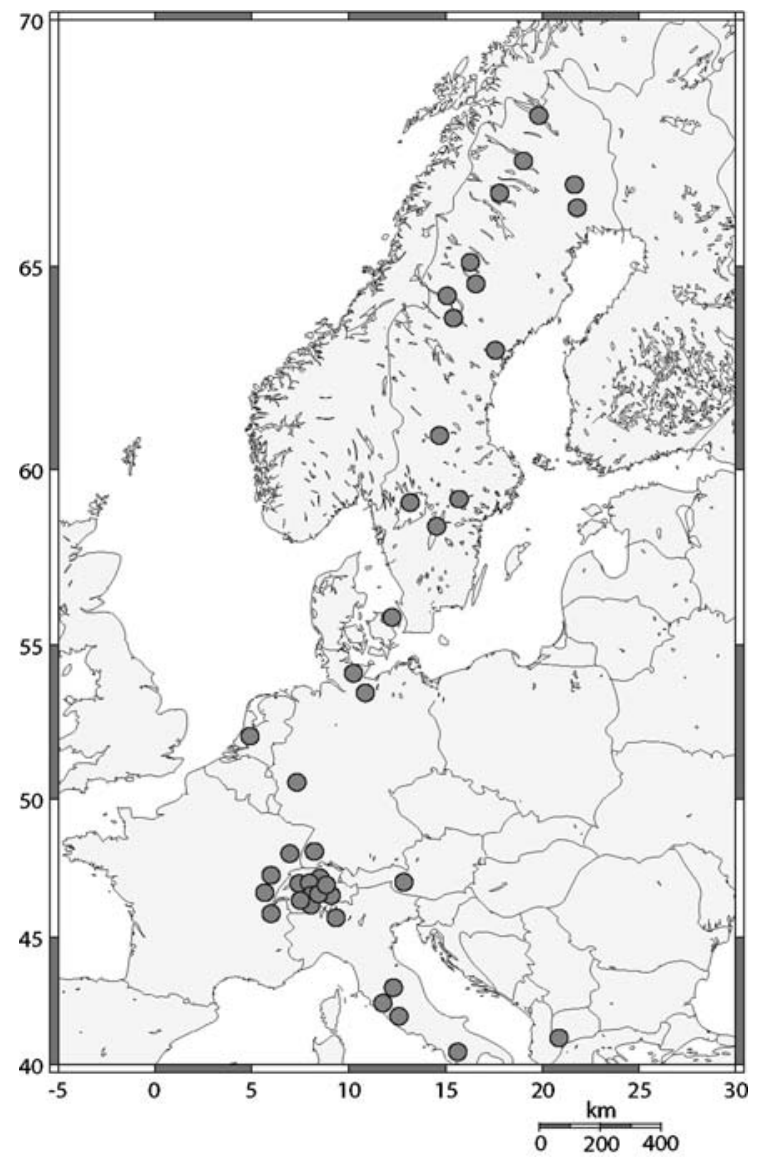

Fig. 1 Location of the 47 lakes studied. Some of the dots plotted in Switzerland represent more than one lake 
sediment-core tops, collected previously from lakes in the Swiss Alps and from Lake Ohrid (Albanian-Macedonian border), were analysed. The surface area, trophic conditions, convective turnover, surface-water temperature, $\mathrm{pH}$ and other environmental variables of the lake water all vary greatly among lakes because of the large latitudinal gradient, the different soils, diverse vegetation communities, and different land uses in their catchments.

Extraction, fractionation and high-performance liquid chromatography (HPLC)

Water filtrates and sediment core tops $(5 \mathrm{~cm})$ that were extruded in the field were stored at $-20^{\circ} \mathrm{C}$. After freeze-drying and, if necessary, homogenization with a mortar and pestle, lipids were extracted from filters and from 1.5 to $2 \mathrm{~g}$ dry sediment. Filters were ultrasonically extracted with methanol, dichloromethane (DCM)/methanol (1:1, v/v) and DCM, each three times. Sediments were extracted using an Accelerated Solvent Extractor (DIONEX ASE 200). A mixture of DCM/methanol $(9: 1 ; \mathrm{v} / \mathrm{v})$ was flushed through at a temperature of $120^{\circ} \mathrm{C}$ and a pressure of $7.6^{*} 10^{6} \mathrm{~Pa}$ three times, with $5 \mathrm{~min}$ intervals between flushings. Extracts were condensed by rotary evaporation, and after drying over a $\mathrm{Na}_{2} \mathrm{SO}_{4}$ column using DCM as an eluent, they were separated by column chromatography for analyses. By using an activated $\mathrm{Al}_{2} \mathrm{O}_{3}$ column, the apolar and polar fractions were obtained with hexane:DCM 9:1 (v/v) and DCM: $\mathrm{MeOH}$ 1:1 (v/v), respectively, as an eluent. The polar fraction was dried under a nitrogen flow, dissolved in hexane:isopropanol 99:1 by sonication, and prior to injection, filtered through a $0.45-\mu \mathrm{m}$ PTFE filter. GDGTs were measured (injection volume $10 \mu \mathrm{l}$ ) using HPLC/atmospheric pressure positive-ion chemical ionization (APCI)/MS according to Schouten et al. 2007a, b. To enable detection of low concentrations of GDGTs, a modification in the scanning procedure was made, as the single ion monitoring (SIM) mode was used to increase sensitivity and reproducibility $(\mathrm{m} / \mathrm{z} 1302,1300,1298,1296,1292$, 1050, 1036 and 1022 for the different GDGT isomers) (Schouten et al. 2007a). Samples used for $\mathrm{TEX}_{86}$ analyses were used also for BIT index analyses (Hopmans et al. 2004). After analyzing the mass chromatograms, peaks that were at least one order of magnitude greater than the background noise were integrated and used for $\mathrm{TEX}_{86}$ and BIT calculation. $\mathrm{TEX}_{86}$ values were determined according to the equation given by Schouten et al. (2002):

TEX $_{86}=\frac{\text { GDGT II + GDGT III + GDGTIV', }}{\text { GDGTI+GDGTII+GDGT III+GDGTIV }}$,

where $\mathrm{I}-\mathrm{IV}^{\prime}$ refer to GDGT structures presented in Fig. 2.

BIT index values were calculated following the equation given by Hopmans et al. (2004) as follows:

$\mathrm{BIT}=\frac{\text { GDGT V }+ \text { GDGT VI }+ \text { GDGT VII }}{\text { GDGT IV + GDGT V + GDGT VI }+ \text { GDGT VII }}$.

\section{Results}

Figure 2 shows HPLC/MS base peak chromatograms revealing the distributions of GDGTs in the surface sediments of three lakes. The distribution of membrane lipids varies greatly among the studied lakes. Isoprenoid and branched GDGTs are found in most of the samples, but there is considerable variation in the distributions. Whereas some distributions are dominated by branched GDGTs, in others GDGT-0 is the major component, and still another group of sediments shows relatively high amounts of crenarchaeol and the other isoprenoid GDGTs produced by Crenarchaeota (Fig. 2). This is also clear from the ternary diagram (Fig. 3a) showing the relative abundance of the major GDGTs (i.e. GDGT-0, crenarchaeol, and the branched GDGTs). In the investigated lacustrine sediments, crenarchaeol is present in concentrations that vary between 0.2 and $49 \%$ of total GDGTs, $29 \%$ on average (Table 1). Overall, crenarchaeol (IV) is the dominant individual isoprenoid GDGT, however, in a substantial number of lake sediments, crenarchaeol is present only in low amounts, whereas it is found in relatively high amounts (26-49\% of total GDGTs) in only 13 of the 47 studied lake sediments (Table 1). In 10 of the investigated lake sediments, some GDGTs were below the detection limit (Table 1). The regio-isomer of crenarchaeol $\left(\mathrm{IV}^{\prime}\right)$ was detected only in trace amounts in most lake sediments $(0.02-0.9 \%$ of total GDGTs), with the exception of Lake St. Moritz, Laachersee, Grosser Plöner See, Maarseveenseplassen, Pfäffikersee, Arendsee and Lago Grande di Monticchio, in which GDGT IV $^{\prime}$ was below the 

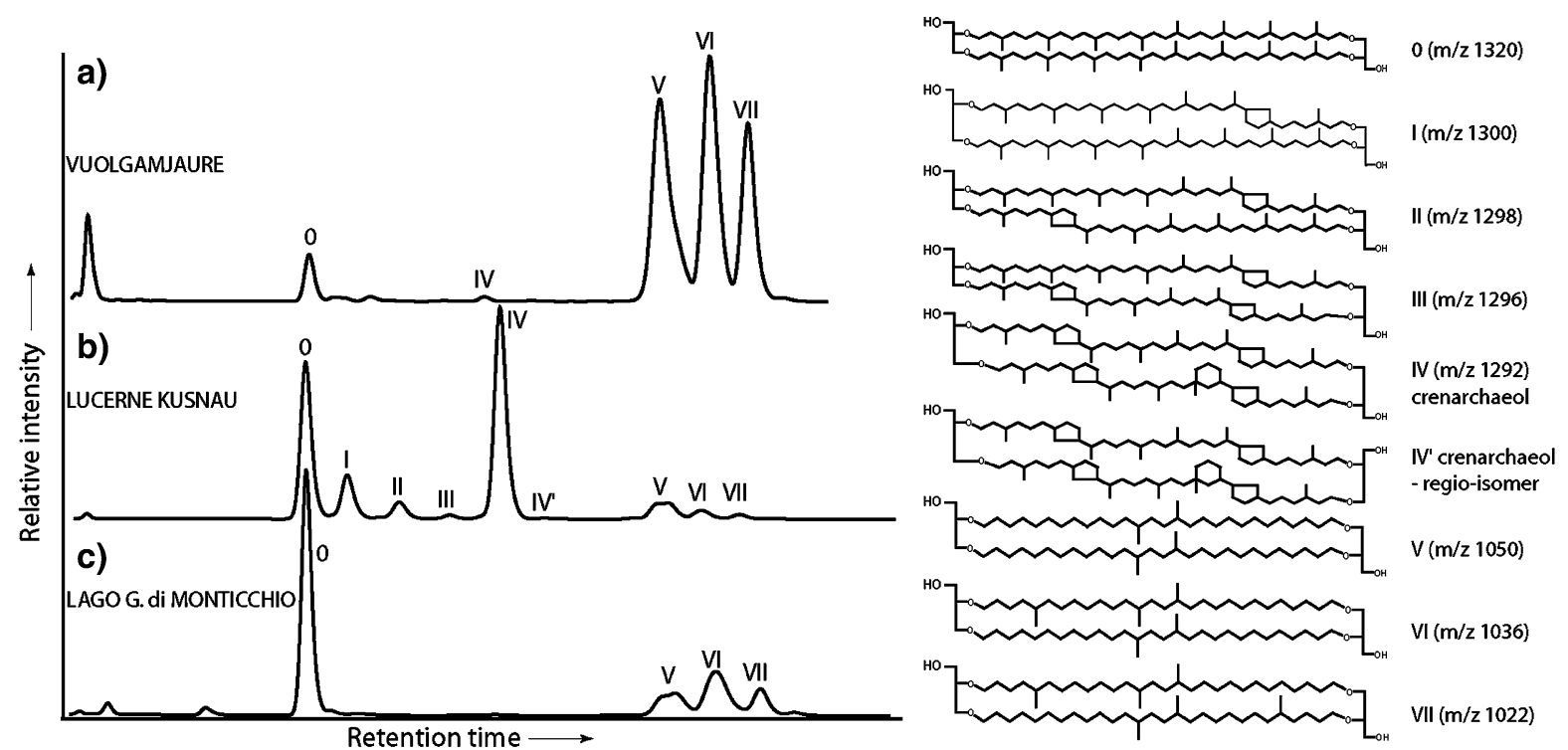

Fig. 2 HPLC/MS base peak chromatograms showing the relative distribution of GDGTs in (a) Lake Vuolgamjaure (Sweden), (b) Lake Lucerne (Küssnachterbecken) (Switzerland), and (c) Lago Grande di Monticchio (Italy). Roman numbers refer to structures of GDGTs indicated in the right

detection limit. In the sediments of these lakes, crenarchaeol was also found in relatively small amounts. GDGT-0 was present in all sediments in substantial amounts (4-72\% of total GDGTs, $28 \%$ on average). GDGT-I, -II and -III were detected, but in smaller amounts and in some lake sediments they are absent (Table 1). Finally, the branched GDGTs (V-VII), produced by an unknown group of anaerobic soil bacteria (Weijers et al. 2006a), dominate the GDGTs in the northern European lake sediments (Fig. 4) and in a few relatively small and shallow lakes from the south.

Particulate organic matter (POM) from the water column of 31 lakes was sampled by filtration of 1-51 of lake water. GDGTs were analysed in these samples, but the amount of material was sometimes not sufficient to obtain reliable distributions of GDGTs. In 24 lakes, however, it was possible to quantify all the major GDGTs (GDGT-0, crenarchaeol and the branched GDGTs) (Table 2). As in the sediments, a large variation in distributions of GDGTs was observed (Fig. 3a). GDGT distributions of POM in some lakes is dominated by crenarchaeol (Lago Maggiore, Lac du Bourget), in other lakes by GDGT-0 (Lac du Joux), but in most lakes by the branched GDGTs. panel. The three base peak chromatograms provide examples of the three end-member GDGT distributions observed in this study: i.e. dominated by soil-derived GDGTs (a), dominated by aquatic crenarchaeotal GDGTs (b), and dominated by a GDGT presumed to derive from methanogens (c)

\section{Discussion}

Potential biological sources for GDGTs

Surface (top $5 \mathrm{~cm}$ ) sediments and POM from the water column of 47 lakes along a south-north transect in Europe show variable distributions of GDGTs. Since GDGTs are membrane lipids produced by both Archaea and Bacteria, sources of GDGTs in lake sediments can be diverse, as in marine environments, soils, peat bogs and hot-water springs (e.g. Schouten et al. 2000; Weijers et al. 2004, 2006b; Pearson et al. 2004).

Crenarchaeol was found in all sediments analysed, with highest concentrations (up to $49 \%$ of total GDGTs) in the Alpine lakes, Lake Ohrid and Lago di Albano, and was also often detected in POM in highly variable relative amounts $(0-58 \%$ of total GDGTs) (Fig. 4). Crenarchaeol is considered to be a specific biomarker for the mesophilic Crenarchaeota Group I (Sinninghe Damsté et al. 2002) and has been detected in marine and lacustrine environments (e.g. Schouten et al. 2000; Powers et al. 2004), in peat bogs (Weijers et al. 2004), and, in relatively low concentrations, in soils 
Fig. 3 (a) Ternary diagram showing the composition of the major GDGTs in the sediments and particulate organic matter from different depths from the 47 lakes of our North-South transect. (b) Ternary diagram showing the composition of the major GDGTs in the sediments from the European lakes in comparison with the composition of the major GDGTs in soils (data from Weijers et al. 2006b), open marine sediments and costal marine sediments as reported by Schouten et al. (2000). The increasing dark grey areas represent the increase in BIT values showing that the lake sediments with high BIT values have a GDGT composition similar to the one observed in soils. Also shown is the line corresponding to a GDGT-0 vs crenarchaeol ratio of 2 in order to indicate that in the lakes where this ratio is higher then 2, GDGT-0 originates from other Archaea than aquatic Crenarchaeota as well (i.e. predominantly methanogens, see text). Lakes plotting in the area of the ternary diagram defined by BIT $<0.4$ and GDGT-0/ crenarchaeol $<2$ (indicated by a bold line) have a potential for $\mathrm{TEX}_{86}$ palaeothermometry. This plot indicates that only 9 of the 47 investigated European lakes fall in this area

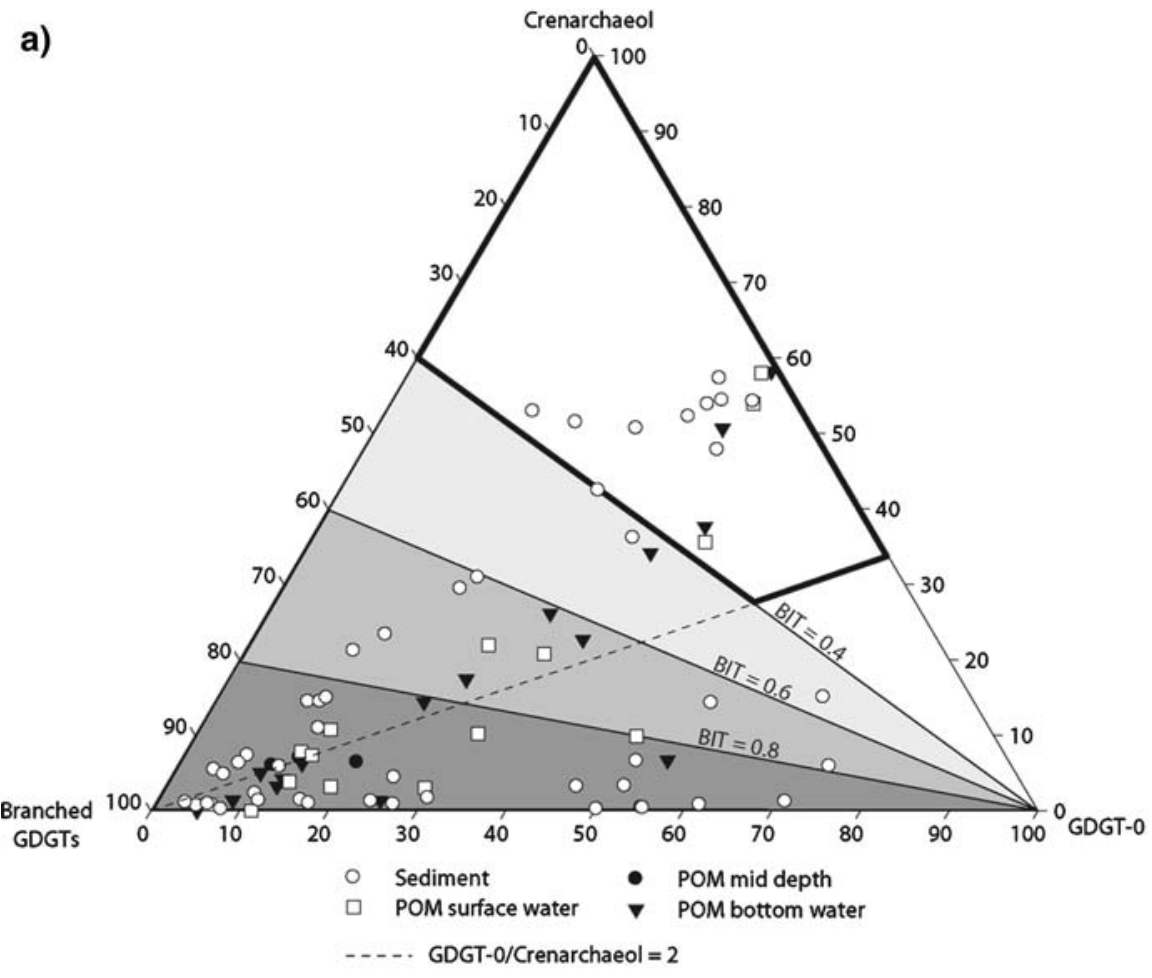

b)

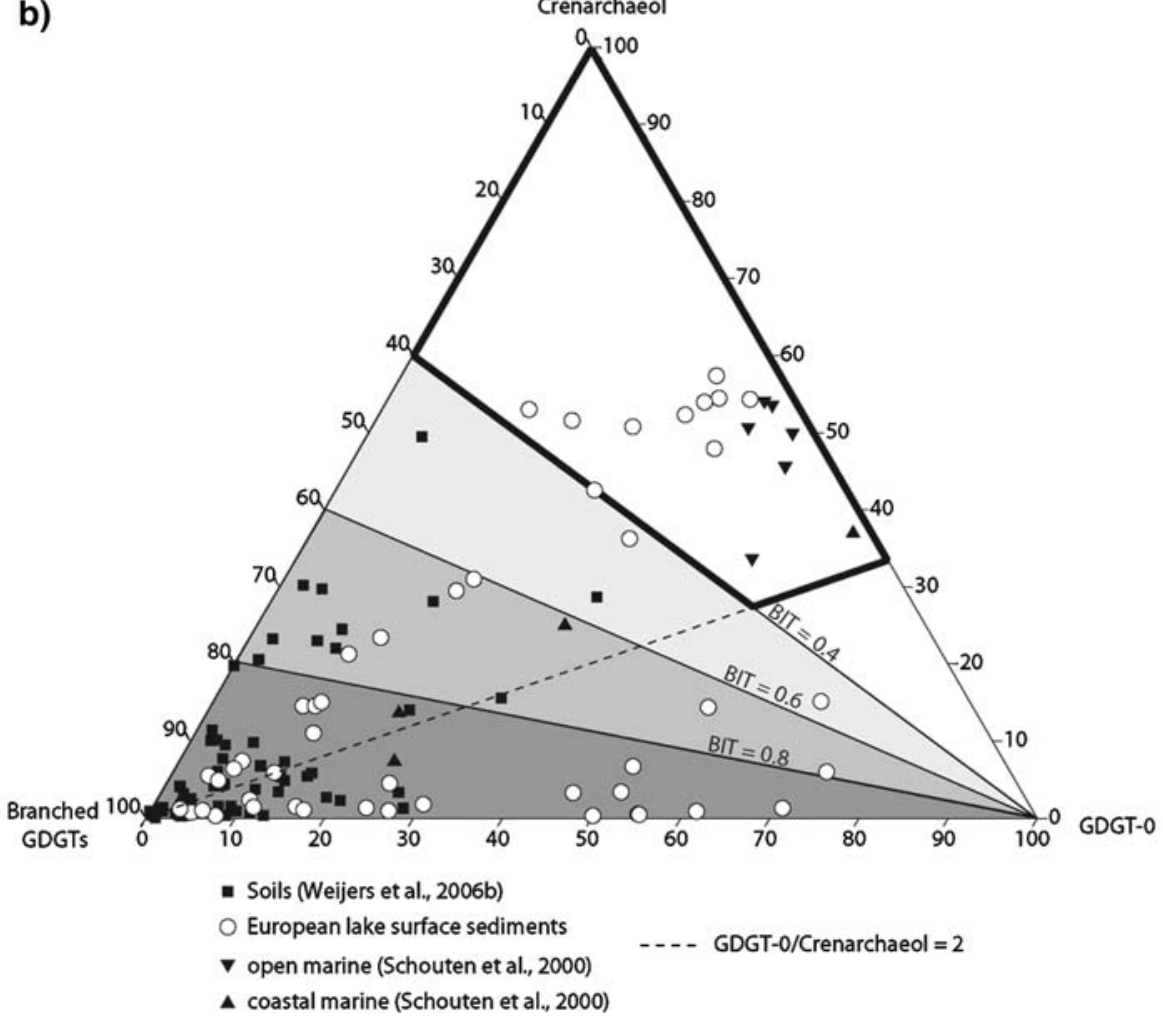




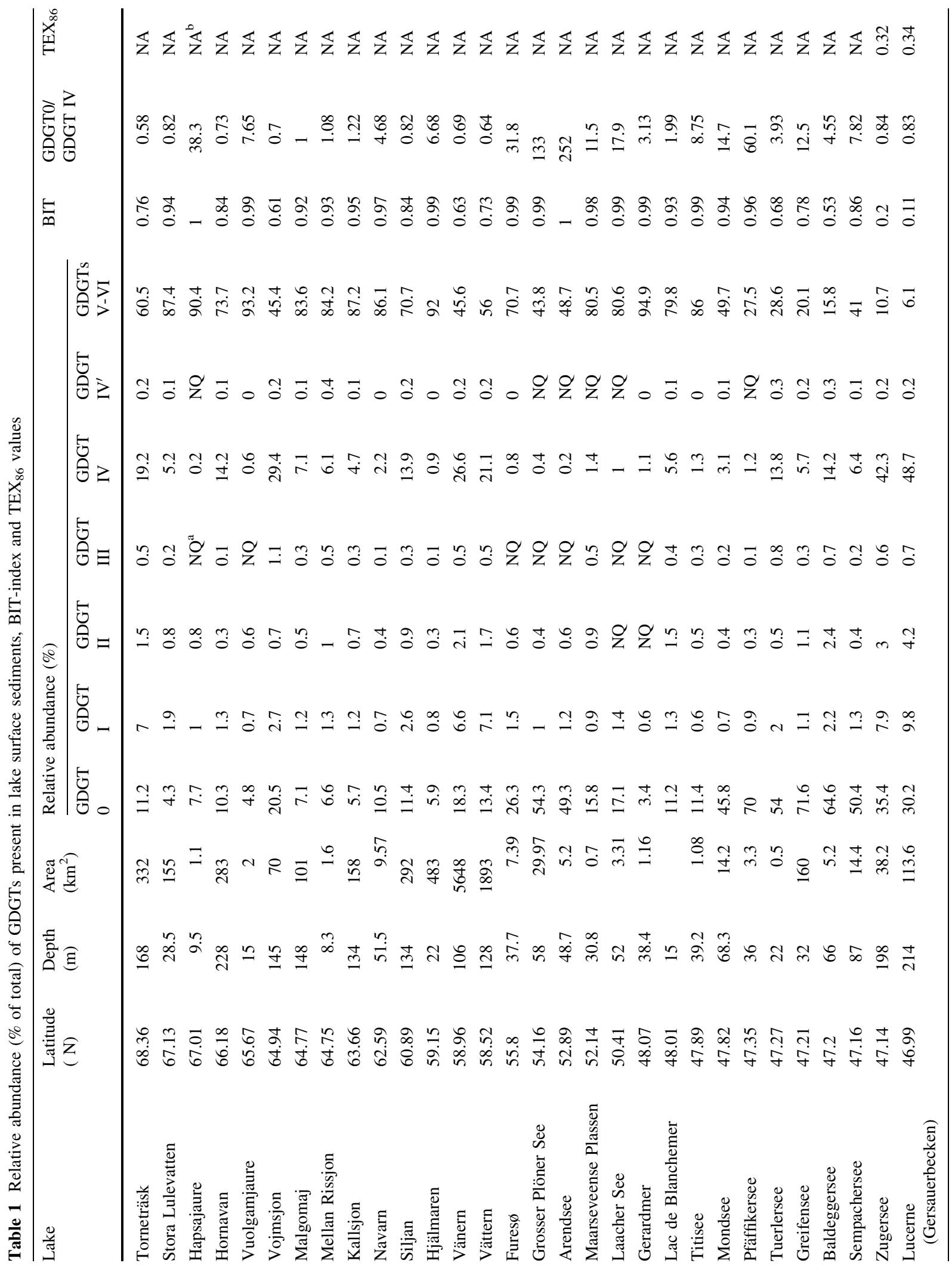




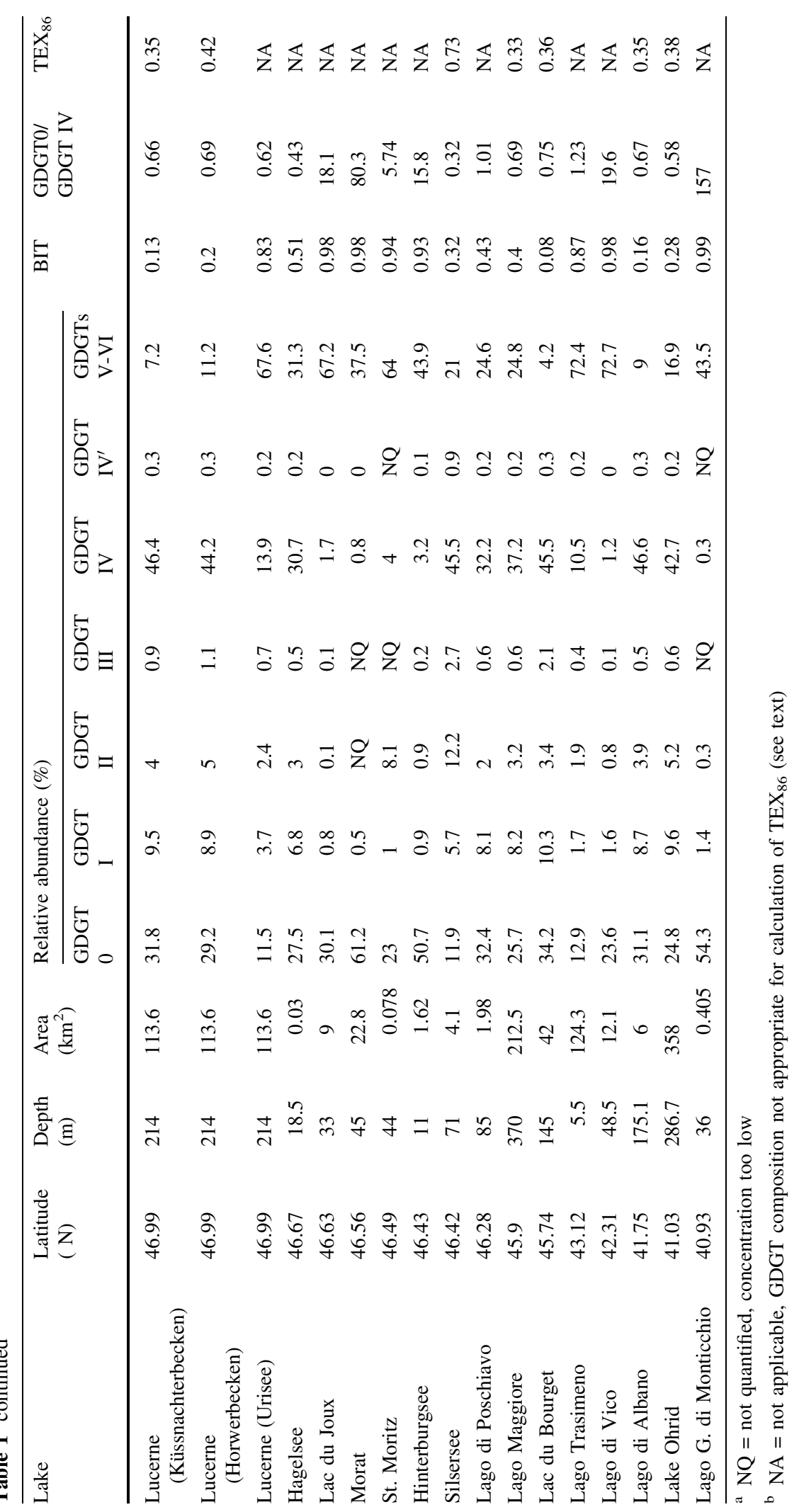


(Weijers et al. 2006b; Leininger et al. 2006), confirming the widespread environmental occurrence of species falling in the Group I Crenarchaeota. Crenarchaeol was also reported in hot springs (Pearson et al. 2004; Zhang et al. 2006), suggesting that crenarchaeol can also originate from thermophilic archaea, as was recently confirmed using an enrichment culture (de la Torre et al. 2008). Schouten et al. (2007b) showed, however, that crenarchaeol in hot springs $>50^{\circ} \mathrm{C}$ most likely derives from erosion of soil. In any case, thermophilic Archaea are an unlikely source for crenarchaeol in the lakes studied. Mesophilic, Group I Crenarchaeota also produce small amounts of the regio-isomer of crenarchaeol (GDGT IV') (Sinninghe Damsté et al. 2002). GDGT-IV' was detected in almost all the sediments, but only in small amounts. In POM it was usually below the limit of detection. The crenarchaeol regio-isomer is known to be abundant in marine environments with temperatures higher than $25^{\circ} \mathrm{C}$ (Wuchter et al. 2004). Considering that our lakes have annual mean water temperatures between 5 and $15^{\circ} \mathrm{C}$, the lack of substantial amounts of the regio-isomer is probably explained by these low temperatures.

GDGT-0 was found in all sediments studied, in relative abundances varying from 3 to $72 \%$ of total GDGTs. It was also detected in relatively high amounts in POM (up to 55\% of total GDGTs) (Fig. 4). GDGT-0 is a rather common membrane lipid of Archaea. It has been reported to occur in both thermophilic Crenarchaeota and Euryarchaeota (Kates et al. 1993), mesophilic Group I Crenarchaeota (Sinninghe Damsté et al. 2002), as well as in methanogens (Koga et al. 1993) and Euryarchaeota that mediate the anaerobic oxidation of methane (Pancost et al. 2001). In POM and sediments from lakes, methanogens and Group I Crenarchaeota are the most likely sources for GDGT-0. In Group I Crenarchaeota the GDGT-0/crenarchaeol ratio is temperature-dependent, but typically varies between 0.2 and 2 (Schouten et al. 2002). Thus we propose that if this ratio is $>2$, it indicates a substantial methanogenic origin for GDGT-0 (see below).

Isoprenoid GDGTs containing 1-3 cyclopentane moieties, together with GDGT-0 and crenarchaeol,

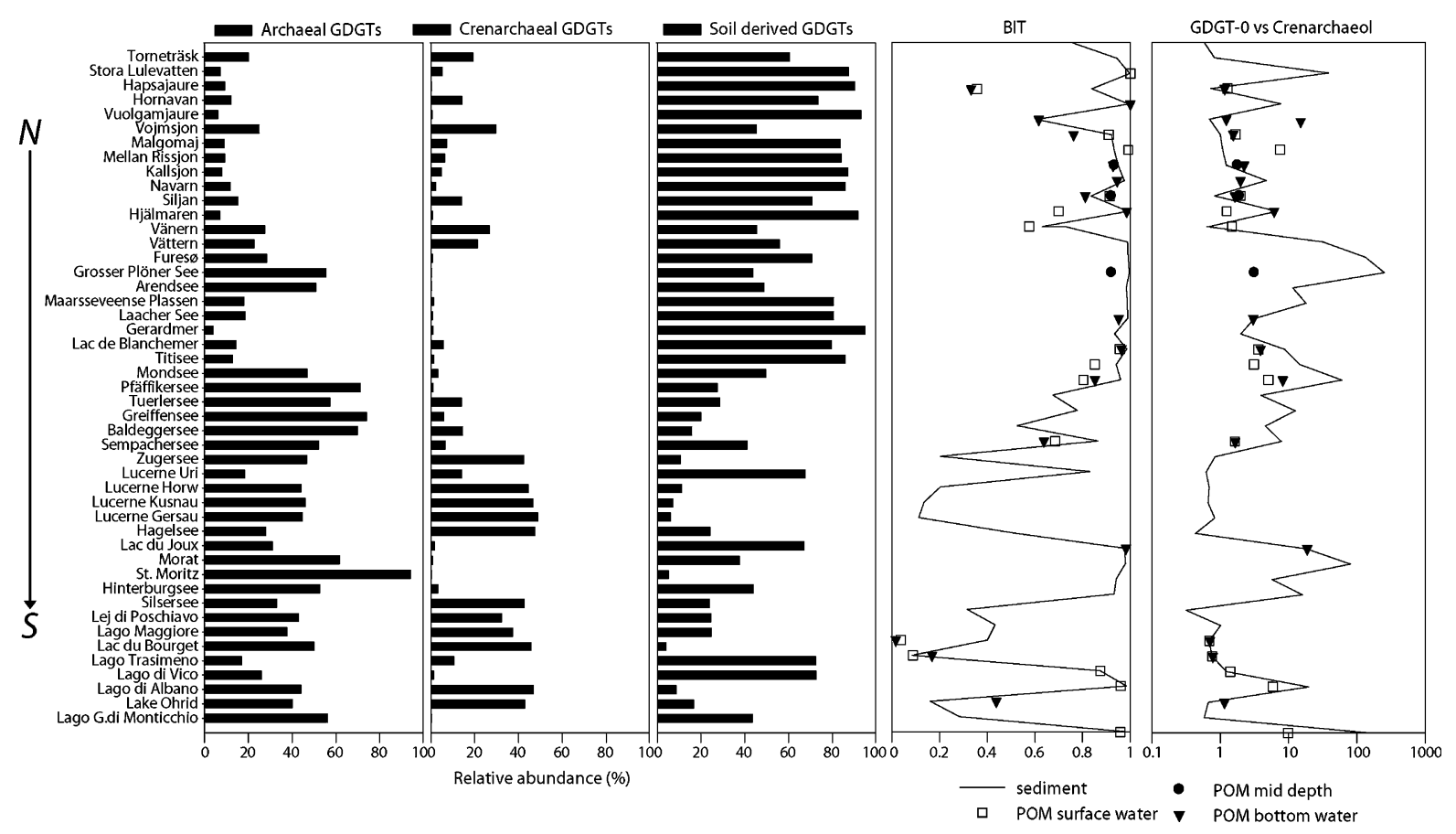

Fig. 4 Relative abundance (\%) of GDGTs, BIT indices and GDGT-0/crenarchaeol ratios for 47 European lake surface sediments. GDGTs are classified according to their origin: archaeal, GDGT-0, -I, -II and -III; Crenarchaeal, GDGTs IV and IV'; $^{\prime}$ soil derived, GDGT V, VI, VII. BIT index and GDGT-0 vs crenarchaeol ratios from the particulate matter from the corresponding lakes are also shown. Note that the GDGT-0/crenarchaeol ratios are plotted on a logarithmic scale 
Table 2 Relative abundance (\% of total) of GDGTs present in lake particulate matter, BIT and TEX 86 values

\begin{tabular}{|c|c|c|c|c|c|c|c|}
\hline \multirow[t]{2}{*}{ Lake } & \multirow{2}{*}{$\begin{array}{l}\text { Latitude } \\
\left({ }^{\circ} \mathrm{N}\right)\end{array}$} & \multirow{2}{*}{$\begin{array}{l}\text { Depth } \\
\text { of POM }\end{array}$} & \multicolumn{3}{|c|}{ Relative abundance (\%) } & \multirow[t]{2}{*}{ BIT } & \multirow{2}{*}{$\begin{array}{l}\text { GDGT-0/ } \\
\text { Crenarchaeol }\end{array}$} \\
\hline & & & GDGT 0 & crenarchaeol & Branched GDGTs & & \\
\hline Hapsajaure & 67.01 & $\mathrm{~s}$ & 11 & 0 & 89 & 1.00 & $\mathrm{NA}^{\mathrm{b}}$ \\
\hline \multirow[t]{2}{*}{ Hornavan } & \multirow[t]{2}{*}{66.18} & $\mathrm{~s}$ & 45 & 36 & 20 & 0.36 & 1.3 \\
\hline & & $\mathrm{b}$ & 44 & 38 & 19 & 0.33 & 1.2 \\
\hline Vuolgamjaure & 65.67 & $\mathrm{~b}$ & 5 & 0 & 95 & 1.00 & NA \\
\hline Vojmsjon & 64.94 & $\mathrm{~b}$ & 32 & 26 & 42 & 0.62 & 1.2 \\
\hline \multirow[t]{2}{*}{ Malgomaj } & \multirow[t]{2}{*}{64.77} & s & 13 & 8 & 79 & 0.91 & 1.7 \\
\hline & & $\mathrm{b}$ & 27 & 17 & 56 & 0.76 & 1.5 \\
\hline Mellan Rissjon & 64.75 & s & 6 & 1 & 93 & 0.99 & 7.5 \\
\hline \multirow[t]{2}{*}{ Kallsjon } & \multirow[t]{2}{*}{63.66} & $\mathrm{~m}$ & 11 & 6 & 83 & 0.93 & 1.8 \\
\hline & & $\mathrm{b}$ & 14 & 6 & 80 & 0.93 & 2.2 \\
\hline Navarn & 62.59 & $\mathrm{~b}$ & 10 & 5 & 85 & 0.94 & 2.0 \\
\hline \multirow[t]{3}{*}{ Siljan } & \multirow[t]{3}{*}{60.89} & s & 14 & 7 & 78 & 0.91 & 2.0 \\
\hline & & $\mathrm{m}$ & 13 & 7 & 80 & 0.92 & 1.9 \\
\hline & & $\mathrm{b}$ & 24 & 14 & 62 & 0.81 & 1.6 \\
\hline \multirow[t]{2}{*}{ Hjälmaren } & \multirow[t]{2}{*}{59.15} & $\mathrm{~s}$ & 27 & 22 & 51 & 0.70 & 1.2 \\
\hline & & $\mathrm{b}$ & 9 & 1 & 90 & 0.98 & 6.1 \\
\hline Vänern & 58.96 & $\mathrm{~s}$ & 39 & 26 & 35 & 0.58 & 1.5 \\
\hline Arendsee & 52.89 & $\mathrm{~m}$ & 20 & 6 & 74 & 0.92 & 3.1 \\
\hline Gerardmer & 48.07 & $\mathrm{~b}$ & 13 & 4 & 83 & 0.95 & 3.0 \\
\hline \multirow[t]{2}{*}{ Titisee } & \multirow[t]{2}{*}{47.89} & $\mathrm{~s}$ & 14 & 4 & 82 & 0.96 & 3.6 \\
\hline & & $\mathrm{b}$ & 13 & 3 & 84 & 0.96 & 3.9 \\
\hline Mondsee & 47.82 & s & 32 & 10 & 58 & 0.85 & 3.1 \\
\hline \multirow[t]{2}{*}{ Pfäffikersee } & \multirow[t]{2}{*}{47.35} & $\mathrm{~s}$ & 50 & 10 & 40 & 0.80 & 5.0 \\
\hline & & $\mathrm{b}$ & 55 & 7 & 38 & 0.85 & 8.2 \\
\hline \multirow[t]{2}{*}{ Sempachersee } & \multirow[t]{2}{*}{47.16} & s & 34 & 21 & 45 & 0.69 & 1.6 \\
\hline & & $\mathrm{b}$ & 37 & 23 & 40 & 0.64 & 1.6 \\
\hline Lac du Joux & 46.63 & $\mathrm{~b}$ & 25 & 1 & 73 & 0.98 & 18.7 \\
\hline \multirow[t]{2}{*}{ Lago Maggiore } & 45.9 & $\mathrm{~s}$ & 40 & 58 & 2 & 0.04 & 0.7 \\
\hline & & $\mathrm{b}$ & 41 & 58 & 1 & 0.02 & 0.7 \\
\hline Lac du Bourget & 45.74 & $\mathrm{~s}$ & 41 & 54 & 5 & 0.09 & 0.8 \\
\hline & & $\mathrm{b}$ & 39 & 51 & 10 & 0.17 & 0.8 \\
\hline Lago Trasimeno & 43.12 & $\mathrm{~s}$ & 15 & 11 & 74 & 0.87 & 1.4 \\
\hline Lago di Vico & 42.31 & s & 19 & 3 & 78 & 0.96 & 5.8 \\
\hline Lago di Albano & 41.75 & $\mathrm{~b}$ & 39 & 34 & 27 & 0.44 & 1.1 \\
\hline Lago G. di Monticchio & 40.93 & s & 29 & 3 & 68 & 0.96 & 9.8 \\
\hline Hapsajaure & 67.01 & $\mathrm{~s}$ & 11 & 0 & 89 & 1.00 & NA \\
\hline Hornavan & 66.18 & s & 45 & 36 & 20 & 0.36 & 1.3 \\
\hline & & $\mathrm{b}$ & 44 & 38 & 19 & 0.33 & 1.2 \\
\hline Vuolgamjaure & 65.67 & $\mathrm{~b}$ & 5 & 0 & 95 & 1.00 & NA \\
\hline Vojmsjon & 64.94 & $\mathrm{~b}$ & 32 & 26 & 42 & 0.62 & 1.2 \\
\hline Malgomaj & 64.77 & $\mathrm{~s}$ & 13 & 8 & 79 & 0.91 & 1.7 \\
\hline & & $\mathrm{b}$ & 27 & 17 & 56 & 0.76 & 1.5 \\
\hline Mellan Rissjon & 64.75 & $\mathrm{~s}$ & 6 & 1 & 93 & 0.99 & 7.5 \\
\hline
\end{tabular}


Table 2 continued

\begin{tabular}{|c|c|c|c|c|c|c|c|}
\hline \multirow[t]{2}{*}{ Lake } & \multirow{2}{*}{$\begin{array}{l}\text { Latitude } \\
\left({ }^{\circ} \mathrm{N}\right)\end{array}$} & \multirow{2}{*}{$\begin{array}{l}\text { Depth } \\
\text { of } \mathrm{POM}^{\mathrm{a}}\end{array}$} & \multicolumn{3}{|c|}{ Relative abundance (\%) } & \multirow[t]{2}{*}{ BIT } & \multirow{2}{*}{$\begin{array}{l}\text { GDGT-0/ } \\
\text { Crenarchaeol }\end{array}$} \\
\hline & & & GDGT 0 & crenarchaeol & Branched GDGTs & & \\
\hline \multirow[t]{2}{*}{ Kallsjon } & \multirow[t]{2}{*}{63.66} & $\mathrm{~m}$ & 11 & 6 & 83 & 0.93 & 1.8 \\
\hline & & $\mathrm{b}$ & 14 & 6 & 80 & 0.93 & 2.2 \\
\hline Navarn & 62.59 & $\mathrm{~b}$ & 10 & 5 & 85 & 0.94 & 2.0 \\
\hline \multirow[t]{3}{*}{ Siljan } & \multirow[t]{3}{*}{60.89} & $\mathrm{~S}$ & 14 & 7 & 78 & 0.91 & 2.0 \\
\hline & & $\mathrm{m}$ & 13 & 7 & 80 & 0.92 & 1.9 \\
\hline & & b & 24 & 14 & 62 & 0.81 & 1.6 \\
\hline
\end{tabular}

${ }^{\mathrm{a}} \mathrm{s}=$ surface water, $\mathrm{m}=$ mid depth, $\mathrm{b}=$ bottom water

b $\mathrm{NA}=$ not applicable

Note that for these analyses only GDGT-0, crenarchaeol and the branched GDGTs could be quantified and therefore, these data are not directly comparable with those in Table 1 . For a number of lakes, the amounts of GDGTs in particulate matter were below the level of quantification

are relatively abundant in the lakes from the southern part of the transect. GDGTs I-III have initially been described in cultures of hyperthermophilic Archaea (De Rosa and Gambacorta 1988), but recent work has shown that GDGTs with cyclopentane moieties are present also in non-extreme environments (Schouten et al. 2000, 2002; Pancost et al. 2003 and references therein). In thermophiles, the biosynthesis of cyclopentane moieties is considered a temperature adaptation (Schouten et al. 2000). Group I Crenarchaeota also produce small amounts of these GDGTs (Sinninghe Damsté et al. 2002) and these components are used in fine-tuning the physical properties of their membrane as an adaptation to temperature (Schouten et al. 2002). Weijers et al. (2006b) found small amounts of GDGTs I-III in soils in a distribution not corresponding to the distribution pattern observed in Group I Crenarchaeota (i.e. dominated by GDGT-0 or crenarchaeol), suggesting an alternative mesophilic crenarchaeal and/or euryarchaeal, potentially methanogenic, source of these components, although they have not yet been reported in mesophilic methanogens (see Table 1 in Schouten et al. 2007b). Certain groups of Archaea involved in the anaerobic oxidation of methane in marine sediments produce GDGTs with 1-3 cyclopentane moieties as major membrane lipids (Pancost et al. 2001; Blumenberg et al. 2004).

The branched GDGTs V-VII were found in all sediment samples and appear to be the most important GDGTs in the POM and sediments of lakes from the northern part of the studied transect (Fig. 4). These GDGTs were discovered in a Dutch peat (Sinninghe
Damsté et al. 2000) and were subsequently detected in coastal sediments, but not in open marine sediments (Schouten et al. 2000; Hopmans et al. 2004). An extended analysis of soils revealed that branched GDGTs occur ubiquitously in soils and are the most important GDGTs (Weijers et al. 2006b). Taken together, this implies that the branched GDGTs are soil-derived and are transported into the aquatic environments predominantly through erosion of soils. The stereochemistry of the glycerol moieties of the branched GDGTs was found to be the bacterial 1,2di-O-alkyl-sn-glycerol stereoconfiguration and not the 2,3-di-O-alkyl-sn-glycerol stereoconfiguration as in archaeal membrane lipids (Weijers et al. 2006a). This demonstrated the bacterial origin of these GDGTs. However, the mesophilic anaerobic bacteria that are thought to produce these membrane lipids are as yet unknown.

\section{Influence of methanogenesis on GDGT} distributions

Approximately half of the lakes investigated in our study are meso- to eutrophic. Because of the relatively high primary productivity in the lakes, there is a substantial organic-matter flux to the sediments, which rapidly becomes anoxic. The dominant anaerobic mineralisation process in lake sediments is methanogenesis. In some of the lakes, even part of the water column is anoxic, so methanogenesis can also occur in the water column. Consequently, methanogenic Archaea may be an important source of GDGTs in POM and sediments of lakes. 
The ratio between GDGT-0 and crenarchaeol can be used to investigate whether methanogenic Archaea are a major source of GDGTs in these sediments. The rationale behind this ratio is that crenarchaeol as well as GDGT-0 can be derived from Group I Crenarchaeota, whereas methanogens synthesize GDGT0 , but no crenarchaeol. Using compound-specific carbon isotope analyses of biphytanes released from GDGTs, Schouten et al. (1998) have shown that in sediments where GDGT-0 was much more abundant than crenarchaeol, there was a significant offset in the stable carbon isotopic compositions of the acyclic and tricyclic biphytane. This suggested an additional, probably methanogenic source of the acyclic GDGT. The lakes that cluster in the right-hand corner of the ternary diagram (Fig. 3a) are characterized by high relative concentrations of GDGT-0, which is indicative of methanogenic activity in the lake. In this ternary diagram, the line for GDGT-0/crenarchaeol ratio $=2$ is plotted: all samples that fall below this line probably have a source for GDGT-0 other than Group I Crenarchaeota. A substantial fraction (47\%) of both sediment and POM samples fall in this area. However, within this group, there is substantial variation: for the sediments, the GDGT-0/crenarchaeol ratio can be as high as 250 , whereas for POM the highest value is 19. In nine of the lakes (Lago Grande di Monticchio, Lago di Vico, Pfäffikersee, Sempachersee, Mondsee, Titisee, Arendsee, Hjälmaren, and Navarn) the GDGT-0 versus crenarchaeol ratio for both water column and sediment shows significant differences (Fig. 4), with higher values of the ratio in the sediment, indicating that GDGT-0 is predominantly derived from methanogens in the sediment. For the other lakes, the values for the ratio are identical. These results strongly suggest that methanogenic Archaea can be an important source of GDGTs in lake settings. However, the fact that in some POM samples from the aerobic part of the water column GDGT-0/crenarchaeol ratios were also $>2$ indicates that in some settings other Archaea than methanogens and Group I Crenarchaeota also produce GDGT-0.

The GDGT-0/crenarchaeol ratio of the sediment from Sempachersee (i.e. 7.8) was substantially higher than that of POM (i.e. 1.6). To investigate the potential contribution of in situ GDGT production by sedimentary methanogenic Archaea, one-centimetre slices of the first $5 \mathrm{~cm}$ from the core top sediment were analysed. A change in the GDGT-0/ crenarchaeol ratio was observed, with values increasing from 3.8 in the first centimetre to 14.3 at $4-5 \mathrm{~cm}$ depth (Fig. 5). This strongly suggests in situ production of GDGT-0 in the sediments from Sempachersee because of ongoing methanogenic activity, altering the GDGT distribution of the lake sediments.

Influence of soil organic-matter input

In soil, the GDGT composition is dominated by branched, glycerol dialkyl glycerol tetraether membrane lipids (Fig. 3b; Weijers et al. 2006a), which are most likely produced by anaerobic bacteria involved in organic-matter mineralization (Weijers et al. 2006b). In many of the lake sediments, the GDGT distribution is similarly dominated by branched GDGTs (Fig. 3b). In marine settings, branched GDGTs are thought to be brought in by rivers through erosion of soils (Hopmans et al. 2004; Herfort et al.

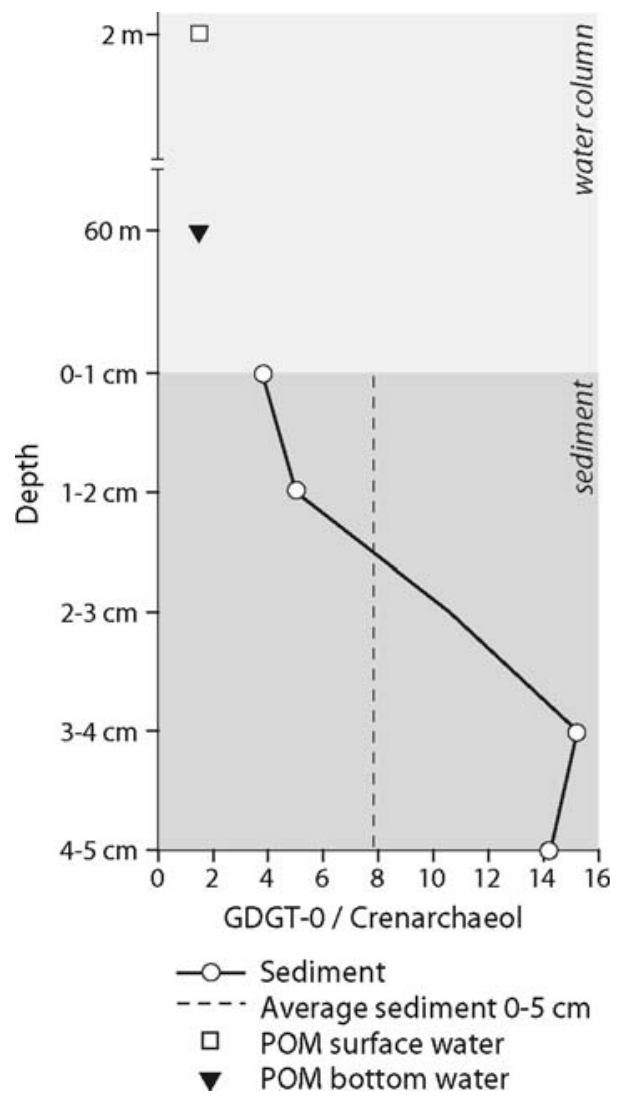

Fig. 5 Ratio between GDGT-0 and crenarchaeol, versus depth in the water column and in the top $5 \mathrm{~cm}$ of sediment from Sempachersee (Switzerland). The stippled line indicates the value of the BIT index for the $0-5 \mathrm{~cm}$ surface sample and reflects the average of the five $1-\mathrm{cm}$ slices 
2006; Kim et al. 2006). In this way, the BIT index is considered to represent the input of terrestrial (i.e. soil) organic matter. Weijers et al. (2006b) measured, in pure soil samples, values for the BIT index mainly between 0.8 and 1 (Fig. 3b). A similar approach can be used for lake settings, although we lack hard evidence that branched GDGTs are not produced in situ in lake waters or sediments. For the set of lakes studied here, BIT index values ranged between 0.08 (Lac du Bourget) and 1.00 (Arendsee) (Table 1; Fig. 4) for the sediment and between 0.02 (Lago Maggiore) and 1.00 for two lakes at high latitude (Hapsajaure, Vuolgamjaure) for POM (Table 2; Fig. 4). Out of the 47 lake sediments and 35 POM samples, 38 and 29, respectively, had BIT values higher than 0.4 (Fig. 3a), a value indicative of a substantial input of terrestrial GDGTs. Significant differences between POM and sediments could be observed in the case of Lago Maggiore, where the values measured in the sediment are higher than the ones from the water column. On the other hand, in Lago Albano the BIT values in the sediment are lower than the ones from the water column. These differences could be explained by the fact that the composition of POM represents only a snapshot of the conditions present in the lakes during the year. The contribution of soil organic matter to the lake, and thus the input of branched GDGTs, may vary through the year, whereas we do not know anything about variations in the seasonal abundance of Group I Crenarchaeota in lakes. In the North Sea there is a strong seasonal cycle in their abundance, with high densities in winter and undetectable levels in summer (Wuchter et al. 2006).

Sediment cores from four different basins in Lake Lucerne were analysed (Fig. 6). Sediments from the Uri basin are dominated by branched GDGTs, as the BIT index has a value of 0.83 , while in the other three basins the index values are 0.1-0.2 (Figs. 4 and 5). A major tributary, the river Reuss, enters Lake Lucerne through the Uri basin thus contributing to the soil organic-matter input which is reflected by the GDGT distribution. The Uri basin is situated in a rectilinear valley exposed to frequent storms that lead to efficient turnovers of the lake (Bührer and Ambühl 2001). This could potentially result in enhanced resuspension of organic matter. However, based on the low BIT index of the other connected sub-basins of Lake Lucerne, this organic matter is apparently not effectively transported further. The decrease in the relative contribution of branched GDGTs to the total GDGTs along the four basins shows that the branched
Fig. 6 Map of Lake Lucerne showing the four different basins and the corresponding BIT values measured in the surface sediments

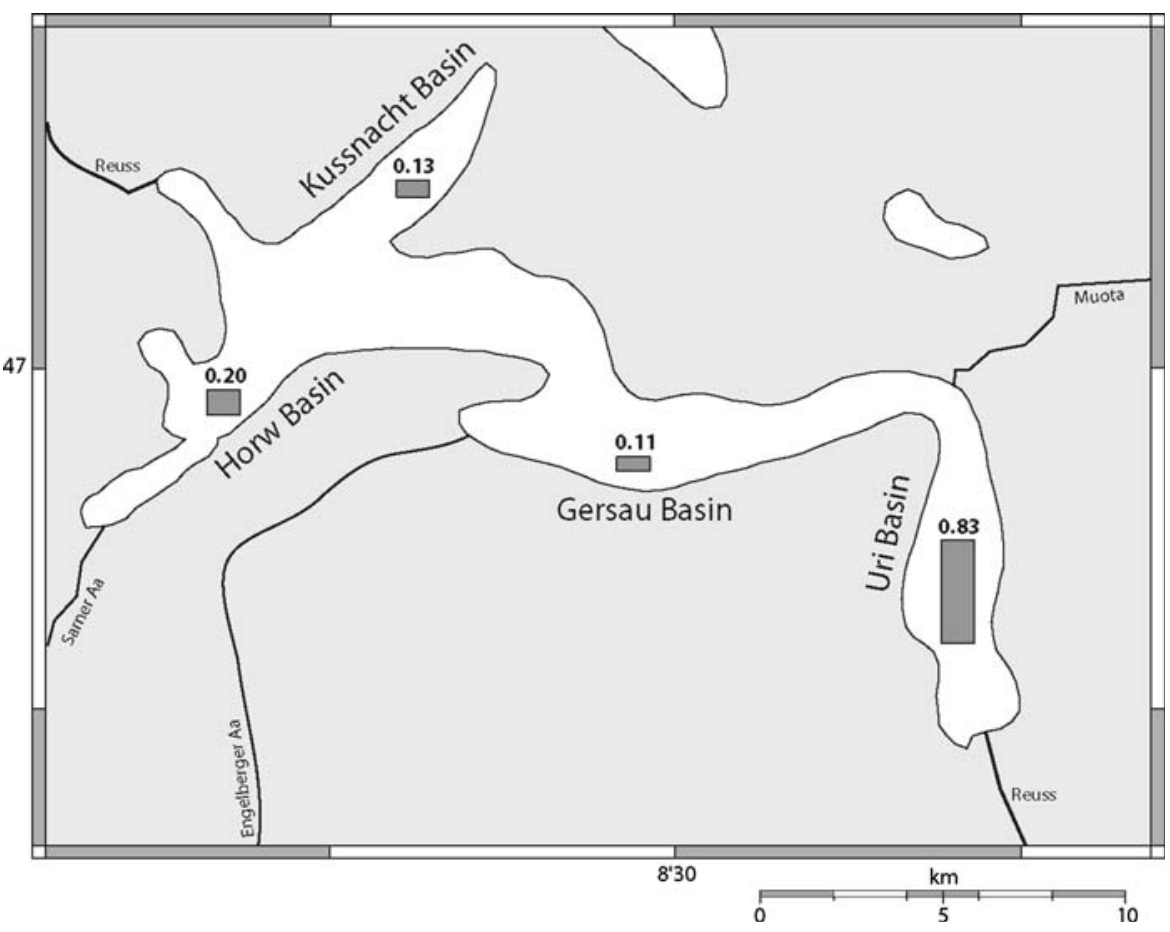


Table 3 Morphometric and hydrologic characteristics of lakes with abundant aquatic GDGTs and low BIT values

\begin{tabular}{|c|c|c|c|c|c|c|c|c|c|}
\hline & $\begin{array}{l}\text { Catchment area } \\
\left(\mathrm{km}^{2}\right)\end{array}$ & $\begin{array}{l}\text { Area } \\
\left(\mathrm{km}^{2}\right)\end{array}$ & $\begin{array}{l}\text { Depth } \\
\text { (m) }\end{array}$ & $\begin{array}{l}\text { Trophic } \\
\text { state }\end{array}$ & $\begin{array}{l}\text { Mixing } \\
\text { regime }\end{array}$ & $\begin{array}{l}\text { ALST } \\
\left({ }^{\circ} \mathrm{C}\right)\end{array}$ & $\begin{array}{l}\text { WLST } \\
\left({ }^{\circ} \mathrm{C}\right)\end{array}$ & $\begin{array}{l}\mathrm{pH}- \\
\text { water }\end{array}$ & References \\
\hline Lac du Bourget & 560 & 42 & 145 & mesotrophic & $\begin{array}{l}\text { meromictic }^{\mathrm{a}} \\
\text { monomictic }^{\mathrm{b}}\end{array}$ & 15.5 & 6.22 & 8.3 & $\begin{array}{l}\text { Jacquet et al. } \\
(2005) \\
\text { Paolini (unpublished } \\
\text { data) }\end{array}$ \\
\hline $\begin{array}{l}\text { Lake Lucerne } \\
\text { (Küssnachter-, } \\
\text { Gersauer-, } \\
\text { Horwerbecken) }\end{array}$ & 2124 & 113.6 & 214 & oligotrophic & $\begin{array}{l}\text { meromictic }^{\mathrm{a}} \\
\text { monomictic }^{\mathrm{b}}\end{array}$ & 11.5 & 5.3 & 8.6 & $\begin{array}{l}\text { Bührer and Ambühl } \\
\text { (2001) }\end{array}$ \\
\hline Lago di Albano & 4 & 6 & 175 & mesotrophic & meromictic & 17.7 & 14 & 8.3 & $\begin{array}{l}\text { Cioni et al. (2003) } \\
\text { Messineo et al. } \\
(2006)\end{array}$ \\
\hline Zugersee & 204 & 39 & 198 & eutrophic & $\begin{array}{l}\text { meromictic }^{\mathrm{a}} \\
\text { monomictic }^{\mathrm{b}}\end{array}$ & 6.9 & 5.7 & 8.0 & DBGZ Switzerland \\
\hline Lake Ohrid & 2600 & 358 & 288 & oligotrophic & oligomictic & 15.7 & 6.3 & 8.3 & $\begin{array}{l}\text { Ocevski and Allen } \\
\text { (1977) }\end{array}$ \\
\hline Silsersee & 46 & 4 & 71 & oligotrophic & dimictic & 2 & 0 & & Blass et al. (2005) \\
\hline Lago Maggiore & 6600 & 213 & 370 & oligotrophic & monomictic $^{\mathrm{b}}$ & 13.2 & 7.2 & 8.4 & $\begin{array}{l}\text { Morabito et al. } \\
(2002)\end{array}$ \\
\hline
\end{tabular}

${ }^{a}$ Lake not thermally stratified during circulation period, may mix completely in some years

${ }^{\mathrm{b}}$ Lake may show an inverse stratification during extremely cold years

GDGTs are likely not produced in situ in the lake, but rather, originate from soil erosion and are brought into the lake by river inflow.

On the European north-south lake transect (Fig. 4), we observe that the GDGT composition of the northern lake sediments and, to a lesser extent, POM, is dominated by branched GDGTs. This contrast between the northern and southern lakes is likely due to differences in soil erosion in the catchments, soil and bedrock types, precipitation characteristics, the abundance of vegetation, hydrology, topography, etc. It may also be related to the in situ aquatic production of archaeal GDGTs in the lakes; most northern lakes are oligotrophic, whereas southern lakes are meso- to eutrophic. Since mesophilic Crenarchaeota in lakes are probably nitrifiers, as in the marine environment (e.g. Wuchter et al. 2006), their production rate is likely dependent on the availability of ammonium, which is primarily derived from decay of organic matter produced by primary producers. At lower in situ production rates of Crenarchaeota, and thus of crenarchaeol, input of soil-derived branched GDGTs may become dominant, which is reflected by high BIT indices.
Group I Crenarchaeota and $\mathrm{TEX}_{86}$ palaeothermometry

The abundance of crenarchaeol in some of the lake sediments and POM samples confirms that Group I Crenarchaeota occur not only in marine environments, but also in lakes (cf. Powers et al. 2004; Powers 2005). Crenarchaeol is detected in almost all lake sediments and POM samples (Tables 1 and 2). However, crenarchaeol has also been reported to occur in soils, albeit in small relative amounts (Leininger et al. 2006; Weijers et al. 2006b), and the GDGT distribution of the lakes studied indicates that many of them have a GDGT distribution comparable to the one of soils (Fig. 3b). In these cases, the presence of crenarchaeol should not be taken as an indication of an active population of Group I Crenarchaeota in the lake.

An interesting application in palaeolimnology is the use of the distribution of fossil GDGTs of Group I Crenarchaeota in the reconstruction of past lake temperature (Powers et al. 2004; Powers 2005). The $\mathrm{TEX}_{86}$ palaeothermometer is based on the distribution of GDGTs present in relatively low abundance (GDGT I-III and IV') (Schouten et al. 2002). As a 
consequence, $\mathrm{TEX}_{86}$ palaeothermometry can only be performed if the source of sedimentary GDGTs is Group I Crenarchaeota. In lake settings, two other known major sources of archaeal GDGTs may impact the $\mathrm{TEX}_{86}$-based palaeotemperature reconstructions: (i) methanogenic Archaea, and (ii) Archaea from soils. GDGT-0 is produced by methanogenic Archaea (Koga et al. 1998a, b) and analysis of environmental samples has led to the belief that they may also produce some of the cyclised derivatives (though in much smaller amounts) (Weijers et al. 2006b; Pancost and Sinninghe Damsté 2003), although this is not confirmed by culture studies (see Table 1 in Schouten et al. 2007b). As explained earlier, if the GDGT-0/crenarchaeol ratio is $>2$, a non-Group I crenarchaeotal origin is evident for GDGT-0, and we believe that in that case GDGTs with cyclopentane moieties may also be derived, in part, from methanogenic Archaea. Therefore, in such a case, we feel it is not appropriate to calculate $\mathrm{TEX}_{86}$ values and infer past lake temperatures.

Branched GDGTs, produced by anaerobic bacteria, are derived and transported in the lakes through soil erosion. Soils also contain small amounts of isoprenoidal GDGTs, including the ones used for TEX $_{86}$ palaeothermometry (Weijers et al. 2006b). Therefore, the BIT index should not be $>0.4$ (cf. Weijers et al. 2006b) when $\mathrm{TEX}_{86}$ will be used for palaeotemperature reconstructions. These constraints define an area in the ternary diagram (Fig. 3a, b) in which lake sediment values should fall if $\mathrm{TEX}_{86}$ is to be applied. Of the 47 lakes studied, only Zugersee, Lake Lucerne (Horwerbecken), Lake Lucerne

a)

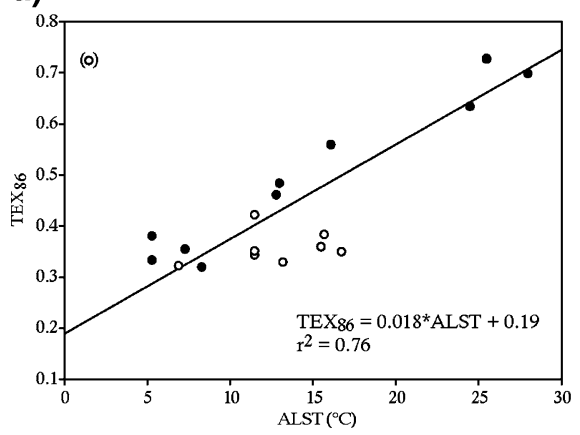

Fig. 7 Linear regression and correlation of $\mathrm{TEX}_{86}$ with: (a) annual mean lake-surface temperature and (b) winter mean lake-surface temperature. White dots represent lakes from the European north-south transect from this study; black dots
(Küssnachterbecken), Lake Lucerne (Gersauerbecken), Silsersee, Lago Maggiore, Lac du Bourget, Lago di Albano and Lake Ohrid had the full complement of GDGTs necessary for calculating TEX $_{86}$, BIT values $<0.4$, and GDGT-0/crenarchaeol ratios $<2$ (Fig. 3b, Table 3).

When the $\mathrm{TEX}_{86}$ values (Table 1) from these 9 lakes are plotted against annual lake-surface temperature, together with data from the study of large lakes by Powers (2005), eight of nine data points follow the general trend (Fig. 7a), although the European lakes studied here cover only a relatively small temperature range. In the case of Silsersee, the $\mathrm{TEX}_{86}$ value translates into an unrealistic lake-surface temperature of $29.5^{\circ} \mathrm{C}$, whereas the true mean annual temperature is $2^{\circ} \mathrm{C}$. In comparison with the other lake sediments, Silsersee had relatively low GDGTs concentrations. Even though the GDGT concentrations were sufficient to be taken into account in the present analysis, it is unclear why this lake represents an outlier. It may be related to an additional, but unknown source of GDGTs. Nevertheless, for calibration purposes we eliminated this data point.

Linear regression of the $\mathrm{TEX}_{86}$ with the mean annual lake-surface temperature for the eight lakes, together with the previously published data set of large lakes, gave the following equation:

$$
\begin{gathered}
\mathrm{TEX}_{86}=0.018 * \text { ALST }+0.19 \\
\left(\mathrm{r}^{2}=0.76, \mathrm{n}=18\right) .
\end{gathered}
$$

$\mathrm{TEX}_{86}$ values were also plotted against mean winter lake-surface temperatures, in which case the correlation coefficient was slightly higher:

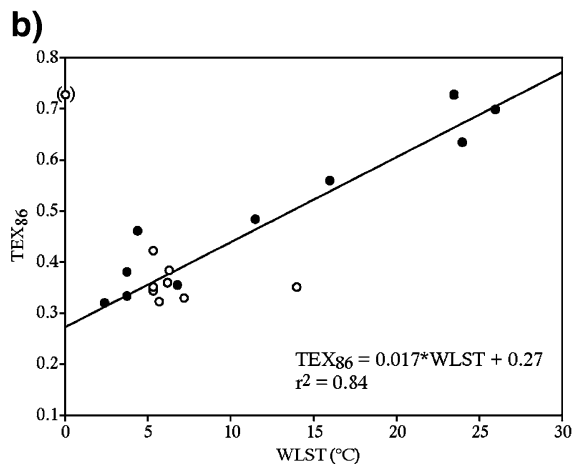

represent large lakes sampled by Powers (2005). The data point for Silsersee is between brackets as it was not included in correlation calculations 
$\mathrm{TEX}_{86}=0.017 * \mathrm{WLST}+0.27\left(\mathrm{r}^{2}=0.84, \mathrm{n}=18\right)$.

The relationship between $\mathrm{TEX}_{86}$ and winter mean temperature appears to be stronger, suggesting that Crenarchaeota bloom in winter or during the early spring months. Indeed, we found in some of the southern lakes that were sampled in winter that the BIT index of POM was substantially lower than that of the surface sediment, implying a higher winter flux of crenarchaeotal GDGTs compared with terrestrial GDGTs. This is in agreement with observations made in the high-latitude lakes by Powers (2005), as well as with time series from the North Sea (Wuchter et al. 2005, 2006).

These results, together with the ones from previous empirical studies, suggest that in some of the lakes GDGTs are being synthesized by mesophilic Crenarchaeota in amounts that allow $\mathrm{TEX}_{86}$ temperature reconstructions. Although GDGTs are present also in smaller lakes, the influence of the factors described above limits the application of $\mathrm{TEX}_{86}$ palaeothermometry in these lakes. The large scatter in the lake $\mathrm{TEX}_{86}$ calibration calls for a detailed investigation of Crenarchaeota ecology in lakes to better understand, for instance, how seasonal changes and water depth influence the relative abundance of the GDGTs in lake systems.

\section{Conclusions}

Our study shows that GDGTs derived from Group I Crenarchaeota are ubiquitous in lakes of all sizes in northern, central and southern Europe, based on the analysis of a wide variety of core-top sediments and water-column POM samples. Production of GDGTs by methanogens in the water column or in the sediments potentially hinders $\mathrm{TEX}_{86}$-based temperature reconstructions. Furthermore, we suggest that the BIT index, as a measure for the input of soil-derived GDGTs, is a reliable tool for assessing which lake sediments are suitable for application of the $\mathrm{TEX}_{86}$ palaeothermometer. It also seems that not only large lakes (Powers et al. 2004) are suitable for TEX $_{86}$ palaeothermometry, but that this palaeotemperature proxy can be applied to reconstruct past climate changes in some intermediate-sized lakes. In some lakes, the ecology and abundance of freshwater Crenarchaeota or other environmental factors might contribute to an offset of $\mathrm{TEX}_{86}$ values from the general temperature-calibration equation.

Acknowledgements We thank A.F. Lotter, F. Verbruggen (Utrecht University), L. Vissers, J.S. Swart (NIOO Nieuwersluis), M. Sturm, F. Anselmetti, A. Zwyssig, A. Blass (EAWAG Dübendorf), G. Nobbe, A. Lami (Istituto Italiano di Idrobiologia Pallanza), F. Arnaud, L. Millet (Université de Savoie, Le Bourget du Lac), G. Paolini (Communauté d'Agglomération du Lac du Bourget) for providing sediment samples from previous fieldwork campaigns and for assistance during fieldwork and $\mathrm{R}$. Laanbroek, A.F. Lotter, G. Muyzer, F. Verbruggen, L. Vissers for helpful discussions. E.C. Hopmans (Royal-NIOZ) is gratefully acknowledged for her support with LC/MS analyses. The Schure-Beijerinck-Popping Fonds provided financial support for the fieldwork. This work was supported financially by the Dutch Darwin Centre for Biogeology.

Open Access This article is distributed under the terms of the Creative Commons Attribution Noncommercial License which permits any noncommercial use, distribution, and reproduction in any medium, provided the original author(s) and source are credited.

\section{References}

Aloisi G, Bouloubassi I, Heijs SK, Pancost RD, Pierre C, Sinninghe Damsté JS, Gottschal JC, Forney LJ, Rouchy JM (2002) $\mathrm{CH}_{4}$-consuming microorganisms and the formation of carbonate crusts at cold seeps. Earth Planet Sci Lett 203:195-203

Blass A, Anselmetti FS, Grosjean M, Sturm M (2005) The last 1300 years of environmental history recorded in the sediments of Lake Sils (Engadine, Switzerland). Ecologae Geol Helv 98:319-332. doi:10.1007/s00015-005-1166-5

Blumenberg M, Seifert R, Reitner J, Pape T, Michaelis W (2004) Membrane lipid patterns typify distinct anaerobic methanotrophic consortia. Proc Natl Acad Sci USA 101:11111-11116. doi:10.1073/pnas.0401188101

Brassell SC, Eglinton G, Howell VJ (1987) Palaeoenvironmental assessment of marine organic rich sediments using molecular organic geochemistry. In: Brooks J, Fleet AJ (eds) Marine petroleum source rocks, geological society special publication no. 26, pp 79-98

Bührer H, Ambühl H (2001) Lake Lucerne, Switzerland, a long term study of 1961-1992. Aquat Sci 63:432-456. doi: 10.1007/s00027-001-8043-8

Cioni R, Guidi M, Raco B, Marini L, Gambardella B (2003) Water chemistry of Lake Albano (Italy). J Volcanol Geotherm Res 120:179-195. doi:10.1016/S0377-0273(02) 00383-9

De Rosa M, Gambacorta A (1988) The lipids of Archaebacteria. Prog Lipid Res 27:153-175

De la Torre JR, Walker CB, Ingalls AE, Könneke M, Stahl DA (2008) Cultivation of a thermophilic ammonia oxidizing 
archaeon synthesizing crenarchaeol. Environ Microbiol 10:810-818

Herfort L, Schouten S, Boon JP, Woltering M, Baas M, Weijers JWH et al (2006) Characterization of transport and deposition of terrestrial organic matter in the southern North Sea using the BIT index. Limnol Oceanogr 51: 2196-2205

Hopmans EC, Weijers JWH, Schefuß E, Herfort L, Sinninghe Damsté JS, Schouten S (2004) A novel proxy for terrestrial organic matter in sediments based on branched and isoprenoid tetraehter lipids. Earth Planet Sci Lett 224:107-116. doi:10.1016/j.eps1.2004.05.012

Hou J, Huang Y, Oswald WW, Foster DR, Shuman B (2007) Centennial-scale compound-specific hydrogen isotope record of Late Pleistocene - Holocene climate transition from southern New England. Geophs Res Let 34. doi: 10.1029/2007GL030303

Huguet C, Kim JH, Sinninghe Damsté JS, Schouten S (2006) Reconstruction of sea surface temperature variations in the Arabian Sea over the last $23 \mathrm{kyr}$ using organic proxies $\left(\mathrm{TEX}_{86}\right.$ and $\left.\mathrm{UK}_{37}{ }^{\prime}\right)$. Paleoceanog 21:PA3003. doi: 10.1029/2005PA001215

Jacquet S, Briand JF, Leboulanger C, Avois-Jacquet C, Oberhaus L, Tassin B et al (2005) The proliferation of the toxic cyanobacterium Planktothrix rubescens following restoration of the largest natural French lake (Lac du Bourget). Harmful Algae 4:651-672. doi:10.1016/j.hal.2003.12.006

Karner MB, DeLong EF, Karl DM (2001) Archaeal dominance in the mesopelagic zone of the Pacific Ocean. Nature 409:507-510. doi:10.1038/35054051

Kates M, Kushner DJ, Matheson AT (1993) The biochemistry of Archaea (Archaebacteria). Elsevier Science Publishers, Amsterdam

Keough BP, Schmidt TM, Hicks RE (2003) Archaeal nucleic acids in Picoplankton from Great Lakes on three continents. Microb Ecol 46:238-248. doi:10.1007/s00248-0031003-1

Kim JH, Schouten S, Buscail R, Ludwig W, Bonnin J, Sinninghe Damsté JS, et al (2006) Origin and distribution of terrestrial organic matter in the NW Mediterranean (Gulf of Lions): application of the newly developed BIT index. Geochem Geophys Geosyst 7, Q11017. doi:10.1029/ 2006GC001306

Kim JH, Schouten S, Hopmans EC, Donner B, Sinninghe Damsté JS (2008) Global sediment core-top calibration of the $\mathrm{TEX}_{86}$ paleothermometer in the ocean. Geochem et cosmochem acta 72:1154-1173

Koga Y, Akagawa-Matsusita M, Ohga M, Nishihara M (1993) Taxonomic significance of the distribution of component parts of polar ether lipids in methanogens. Syst Appl Microbiol 16:342-351

Koga Y, Morii H, Akagawa-Matsushita M, Ohga M (1998b) Correlation of polar lipid composition with 16S rRNA phylogeny in methanogens. Further analysis of lipid component parts. Biosci Biotechnol Biochem 62:230236. doi:10.1271/bbb.62.230

Koga Y, Kyuragi T, Nishihara M, Sone N (1998a) Did archaeal and bacterial cells arise independently from noncellular precursors? A hypothesis stating that the advent of membrane phospholipid with enantiomeric glycerophosphate backbones caused the separation of the two lines of descent. J Mol Evol 46:54-63. doi:10.1007/PL00006283

Leininger S, Urich T, Schloter M, Schwark L, Qi L, Nicol GW et al (2006) Archaea predominate among ammoniaoxidizing prokaryotes in soils. Nature 442:806-809. doi: 10.1038/nature04983

Liu Z, Henderson ACG, Huang Y (2006) Alkenone-based reconstruction of late Holocene surface temperature and salinity changes in Lake Qinghai, China. Geophys Res Lett 33. doi:10.1029/2006GL026151

Messineo V, Mattei D, Melchiorre S, Salvatore G, Bogialli S, Salzano R, Mazza R, Capelli G, Bruno M (2006) Microcystin diversity in a Planktothrix rubescens population from Lake Albano (Central Italy). Toxicon 48:160-174. doi:10.1016/j.toxicon.2006.04.006

Meyers PA (2003) Applications of organic geochemistry to paleolimnological reconstructions: a summary of examples from the Laurentian Great Lakes. Org Geochem 34:261-289. doi:10.1016/S0146-6380(02)00168-7

Morabito G, Ruggiu D, Panzani P (2002) Recent dynamics (1995-1999) of the phytoplankton assemblages in Lago Maggiore as a basic tool of defining association patterns in the Italian deep lakes. J Limnol 61:129-145

Ocevski BT, Allen HL (1977) Limnological studies in a large, deep, Oligotrophic Lake (Lake Ohrid, Yugoslavia). Arch Hydrobiol 79:429-440

Pancost RD, Baas M, van Geel B, Sinninghe Damsté JS (2003) Response of an ombrotrophic peat to a regional climatic event revealed by macrofossil, molecular, and carbon isotopic data. The Holocene 13:921-993

Pancost RD, Hopmans EC, Sinninghe Damsté JS, the MEDINAUT Shipboard Scientific Party (2001) Archaeal lipids in Mediterranean cold seeps: molecular proxies for anaerobic methane oxidation. Geochim Cosmochim Acta 65:1611-1627. doi:10.1016/S0016-7037(00)00562-7

Pancost RD, Sinninghe Damsté JS (2003) Carbon isotopic compositions of prokaryotic lipids as tracers of carbon cycling in diverse settings. Chem Geol 195:29-58. doi: 10.1016/S0009-2541(02)00387-X

Pearson A, Huang Z, Ingalls AE, Romanek CS, Wiegel J, Freeman KH et al (2004) Nonmarine crenarchaeol in Nevada hot springs. Appl Environ Microbiol 70:52295237. doi:10.1128/AEM.70.9.5229-5237.2004

Powers LA (2005) Calibration and application of a new paleotemperature tool in lacustrine systems: $\mathrm{TEX}_{86}$ for continental paleoclimate reconstruction. $\mathrm{PhD}$ thesis, University of Minnesota

Powers LA, Werne JP, Johnson TC, Hopmans EC, Sinninghe Damsté JS, Schouten S (2004) Crenarchaeotal membrane lipids in lake sediments; a new paleotemperature proxy for continental paleoclimate reconstruction? Geology 32:613-616. doi:10.1130/G20434.1

Rullkötter J (2000) Organic matter: the driving force for early diagenesis. In: Schulz HD, Zabel M (eds) Marine Geochemistry. Springer-Verlag, Berlin, pp 129-172

Schouten S, Hoefs MJL, Koopmans MP, Bosch H-J, Sinninghe Damsté JS (1998) Structural identification, occurrence and fate of archaeal ether-bound acyclic and cyclic biphytanes and corresponding diols in sediments. Org Geochem 29:1305-1319. doi:10.1016/S0146-6380(98)00131-4 
Schouten S, Hopmans EC, Pancost RD, Sinninghe Damsté JS (2000) Widespread occurrence of structurally diverse tetraether membrane lipids: evidence for the ubiquitous presence of low-temperature relatives of hyperthermophiles. Proc Natl Acad Sci USA 97:14421-14426. doi: 10.1073/pnas.97.26.14421

Schouten S, Hopmans EC, Schefuß E, Sinninghe Damsté JS (2002) Distributional variations in marine crenarchaeotal membrane lipids: a new tool for reconstructing ancient sea water temperatures? Earth Planet Sci Lett 204:265-274. doi:10.1016/S0012-821X(02)00979-2

Schouten S, Hopmans EC, Kuypers MMM, Breugel Y, Forster A, Sinninghe Damsté JS (2003) Extreme high sea water temperatures at low latitudes during the middle Cretaceous as revealed by archaeal membrane lipids. Geology 31:1069-1072. doi:10.1130/G19876.1

Schouten S, Huguet C, Hopmans EC, Sinninghe Damsté JS (2007a) Improved analytical methodology of the $\mathrm{TEX}_{86}$ paleothermometry by high performance liquid chromatography /atmospheric pressure chemical ionization-mass spectrometry. Anal Chem 79:2940-2944. doi: $10.1021 / \mathrm{ac} 062339 \mathrm{v}$

Schouten S, van der Meer MTJ, Hopmans EC, Rijpstra WIC, Reysenbach AL, Ward DM et al (2007b) Archaeal and bacterial glycerol dialkyl glycerol tetraether lipids in hot springs of Yellowstone national park. Appl Environ Microbiol 73:6181-6191. doi:10.1128/AEM.00630-07

Schouten S, Hopmans EC, Bass M, Boumann H, Standfest S, Könneke M, Stahl DA, Sinninghe Damsté JS (2008a) Intact membrane lipids of Candidatus Nitrosopumilus maritimus a cultivated representative of the cosmopolitan mesophilic group I crenarchaeota. Appl Environ Microbiol 74:2433-2440

Schouten S, van der Meer MTJ, Hopmans EC, Sinninghe Damsté JS (2008b) Comment on "Lipids of marine Archaea: patterns and provenance in the water-column and sediments" by Turich et al. (2007). Geochem et cosmochem acta. doi:10.1016/j.gca.2008.03.028

Sinninghe Damsté JS, Hopmans EC, Pancost RD, Schouten S, Geenevasen JAJ (2000) Newly discovered non-isoprenoid glycerol dialkyl glycerol tetraether lipids in sediments. Chem Commun (Camb) 1683-1684. doi:10.1039/b00 $4517 \mathrm{i}$

Sinninghe Damsté JS, Hopmans EC, Schouten S, van Duin ACT, Geenevasen JAJ (2002) Crenarchaeol: the characteristic core glycerol dibiphytanyl glycerol tetraether membrane lipid of cosmopolitan pelagic crenarchaeota. J Lipid Res 43:1641-1651. doi:10.1194/jlr. M200148-JLR200

Sluijs A, Schouten S, Pagani M, Woltering M, Brinkhuis H, Sinninghe Damsté JS et al (2006) Subtropical Arctic Ocean temperatures during the Palaeocene Eocene thermal maximum. Nature 441:610-613. doi:10.1038/ nature 04668

Weijers JWH, Schouten S, van der Linden M, van Geel B, Sinninghe Damsté JS (2004) Water table related variations in the abundance of intact archaeal membrane lipids in a Swedish peat bog. FEMS Microbiol Lett 239:51-56. doi:10.1016/j.femsle.2004.08.012

Weijers JWH, Schouten S, Hopmans EC, Geenevasen JAJ, David ORP, Coleman JM et al (2006a) Membrane lipids of mesophilic anaerobic bacteria thriving in peats have typical archaeal traits. Environ Microbiol 8:648-657. doi: 10.1111/j.1462-2920.2005.00941.x

Weijers JWH, Schouten S, Spaargaren OC, Sinninghe Damsté JS (2006b) Occurrence and distribution of tetraether membrane lipids in soils: implications for the use of the TEX $_{86}$ proxy and the BIT index. Org Geochem 37:16801693. doi:10.1016/j.orggeochem.2006.07.018

Wuchter C, Schouten S, Coolen MJL, Sinninghe Damsté JS (2004) Temperature-dependent variation in the distribution of tetraether membrane lipids of marine Crenarchaeota: implications for $\mathrm{TEX}_{86}$ paleothermometry. Paleoceanography 19:PA4028. doi:10.1029/2004PA 001041

Wuchter C, Schouten S, Wakeham SG, Sinninghe Damsté JS (2005) Temporal and spatial variation in tetraether membrane lipids of marine Crenarchaeota in particulate organic matter: Implications for $\mathrm{TEX}_{86}$ paleothermometry. Paleoceanography 20:PA3013. doi:10.1029/2004PA 001110

Wuchter C, Abbas B, Coolen MJL, Herfort L, van Bleijswijk J, Timmers P et al (2006) Archaeal nitrification in the ocean. Proc Natl Acad Sci USA 103:12317-12322. doi:10.1073/ pnas.0600756103

Zhang CL, Pearson A, Li YL, Mills G, Wiegel J (2006) Thermophilic temperature optimum for crenarchaeol synthesis and its implication for archaeal evolution. Appl Environ Microbiol 72:4419-4422. doi:10.1128/AEM. 00191-06 